\title{
A General Method for Fusion of the Escherichia coli lacZ Gene to Chromosomal Genes in Bacillus subtilis
}

\author{
By JEFF ERRINGTON \\ Microbiology Unit, Department of Biochemistry, University of Oxford, South Parks Road, \\ Oxford OXI $3 Q U, U K$
}

(Received 11 March 1986; revised 5 June 1986)

\begin{abstract}
A series of plasmids has been constructed that can be used to fuse the $\beta$-galactosidase gene (lac $Z$ ) of Escherichia coli to chromosomal genes of Bacillus subtilis. Insertion of the lacZ gene is facilitated by the use of a selectable chloramphenicol acetyl-transferase (cat) gene. The latter is included, along with the lac $Z$ gene, in a single DNA fragment or 'cartridge' that can be removed from the plasmid with a variety of different restriction endonucleases. Methods applicable to any cloned $B$. subtilis gene are described that enable the lac-cat cartridge to be inserted at specific sites, or at random, directly into the $B$. subtilis chromosome in a single step. These singlecopy chromosomal fusions can be readily transferred, by selection for chloramphenicol resistance, to a temperate phage such as $\phi 105$, to permit a more extensive genetic analysis of the expression of the target gene. Alternatively, the lac-cat cartridge and flanking DNA sequences can be transferred into different genetic backgrounds by transformation. These techniques have been used to construct, in a single step, lac fusions to genes in the sporulation operons spoIIA and spoVA.
\end{abstract}

\section{INTRODUCTION}

A major limitation in studying the control of expression of sporulation genes in Bacillus subtilis has been the difficulty of assaying directly the product of any spo gene. In other systems where a similar problem has been encountered, a useful approach has been to fuse the gene to the coding region of the lac $Z$ ( $\beta$-galactosidase) gene from Escherichia coli (Casadaban et al., 1983), for which a very sensitive and convenient assay is available (Miller, 1972). This approach has also been applied recently with some success to the study of sporulation genes (Zuber \& Losick, 1983; Stephens et al., 1984; Piggot et al., 1985).

Two main types of fusion can be obtained. (i) Translational (gene) fusions are constructed by joining, in frame, a truncated form of the lac $Z$ gene that lacks the coding region for the first 20 to 30 amino acids of $\beta$-galactosidase to the coding region of a heterologous gene. The appearance of $\beta$-galactosidase activity is then an indication of translation of the target operon. This type of fusion is feasible because the first 30 amino acids encoded by the lac $Z$ gene can be replaced by a variety of other protein sequences to produce a hybrid protein that often has substantial $\beta$ galactosidase activity (Brickman et al., 1979). The success of a translational fusion thus depends on two factors: first, maintenance of the correct reading frame through the junction of the fused genes; second, retention of $\beta$-galactosidase activity by the fusion peptide. Since certain in-frame gene fusions do not produce an active product it is often desirable to be able to insert a fragment of DNA containing the truncated lac $Z$ gene at several different locations, or, preferably, at random. To facilitate this kind of approach, Casadaban et al. (1983) have constructed a plasmid, pMC1871, that contains a suitable truncated version of the lac $Z$ gene on a $3.0 \mathrm{kbp}$ segment of DNA which is bounded by a series of unique restriction sites. The gene can therefore be

Abbreviations: RBS, ribsome-binding site; ORF, open reading frame. 
removed as a single fragment of DNA or 'cartridge' by cleavage at any of the flanking restriction sites and re-cloned into target DNA that has cleavage sites for compatible restriction endonucleases. (ii) Transcriptional (operon) fusions are constructed by inserting the complete lac $Z$ gene, including its translation initiation signals but not its promoter, into the transcription unit of another gene. The appearance of $\beta$-galactosidase activity is then used as an indication of transcription of the target operon. This type of fusion can be made at almost any point in an operon provided that the orientation of the $l a c Z$ gene is correct and that the ribosome-binding site (RBS) and initiation codon of the $l a c Z$ gene are suitable for the initiation of translation in the host strain. Unfortunately, the lac $Z$ gene seems not to be efficiently translated in $B$. subtilis (Donnelly \& Sonenshein, 1984), presumably because of low homology between the lac Z RBS and the 3'-end of the 16S ribosomal RNA of B. subtilis (Moran et al., 1982).

However, as described in this paper this problem can be circumvented by replacing the translation initiation signals of the $l a c Z$ gene with sequences that are functional in $B$. subtilis. The genes are contained in a segment of DNA, the lac-cat cartridge, that can be released by digestion with any of several different restriction endonucleases. Methods are described that enable the lac-cat cartridge to be inserted, in a single step, directly into any region of the $B$. subtilis chromosome that has been cloned. The resultant single copy chromosomal fusions can be analysed in situ, or can readily be transferred to the prophage of temperate bacteriophage $\phi 105$ for further genetic analysis.

The following papers describe the application of this system to the study of the regulation of sporulation operons spoIIA (Errington \& Mandelstam, 1986a), spoVA (Errington \& Mandelstam, 1986b), spoIID (Clarke et al., 1986) and spoIIIC (Turner et al., 1986).

\section{METHODS}

Bacterial strains, plasmids and bacteriophages. Bacterial strains and plasmids and their sources are described in Table 1. Strain JM109F- was derived by treatment of strain JM109 with acridine orange (Hirota, 1960), followed by screening for a Pro ${ }^{-}$phenotype. Bacteriophage $\phi 105 D S 1$ (Savva \& Mandelstam, 1984) is a derivative of bacteriophage $\phi 105 \mathrm{DI}$ : $1 \mathrm{t}$ (Flock, 1977) that contains a $7 \mathrm{kbp}$ fragment of $B$. subtilis chromosomal DNA and can complement all known mutations in the spoIIA and spoVA sporulation loci. Bacteriophage M13mp18 (Norrander et al., 1983) was kindly provided by J. Messing, University of Minnesota, USA.

B. subtilis techniques. Methods for preparation of chromosomal DNA and transformation of competent cells were as described by Errington \& Mandelstam (1983). Techniques using phage $\phi 105$ have been described elsewhere (Jenkinson \& Mandelstam, 1983; Errington, 1984). Transduction of the 'tail-less' defective phage $\phi 105 \mathrm{DS} 1$ and its derivatives was achieved in the presence of 'helper' phage as described by Jenkinson \& Mandelstam (1983) except that phage $\phi 105 \mathrm{DI}: 1 \mathrm{t}$ was used as helper.

$E$. coli techniques. DNA-mediated transformation of cells, preparation of plasmid DNA, agarose gelelectrophoresis, preparation of plasmid DNA, restriction endonuclease digestions, isolation of DNA from lowmelting-point agarose and ligations were done as described previously (Errington, 1984; Fort \& Errington, 1985). DNA molecules with 5'-protruding ends were repaired using the Klenow fragment of DNA polymerase I (Klenow polymerase, New England BioLabs) in $30 \mu \mathrm{l}$ reaction volumes containing $1 \mu \mathrm{g}$ DNA, 0.5 unit of enzyme and all four deoxynucleoside triphosphates $(0.5 \mathrm{~mm}$ each). The reaction was done in restriction endonuclease buffer $(<50 \mathrm{mM}-\mathrm{NaCl})$ for $10 \mathrm{~min}$ at $22^{\circ} \mathrm{C}$ and was terminated by extraction with phenol. The DNA was then recovered by ethanol precipitation. Nuclease-S1 (New England BioLabs) was used to remove single-stranded DNA protruding ends in a $30 \mu \mathrm{l}$ reaction volume containing $2 \mu \mathrm{g}$ DNA, $50 \mathrm{~mm}$-sodium acetate $(\mathrm{pH} 4 \cdot 0), 50 \mathrm{~mm}-\mathrm{NaCl}$, $6 \mathrm{mM}-\mathrm{ZnSO}_{4}$ and 50 units of enzyme. After $10 \mathrm{~min}$ at $22^{\circ} \mathrm{C}$ the reaction was terminated by the addition of $0.2 \mathrm{vol}$. of a solution containing $0.1 \mathrm{M}$-EDTA and $1.5 \mathrm{M}$-sodium acetate. After extraction with phenol the DNA was precipitated by the addition of 2 vols ethanol and recovered by centrifugation in the usual manner (Guo et al., 1983).

Selection of transformants. B. subtilis cells containing an integrated lac-cat cartridge (see Results) were selected on Oxoid nutrient agar containing chloramphenicol (Sigma; $5 \mu \mathrm{g} \mathrm{ml}^{-1}$ ). E. coli cells containing pUC plasmids or their derivatives were selected on Oxoid nutrient agar containing ampicillin (Sigma; sodium salt, $50 \mu \mathrm{g} \mathrm{ml}^{-1}$ ) or chloramphenicol $\left(12.5 \mu \mathrm{g} \mathrm{ml}^{-1}\right)$.

Detection and assay of $\beta$-galactosidase activity. The chromogenic substrate 5-bromo-4-chloro-3-indolyl $\beta$-Dgalactopyranoside (X-gal; Sigma) was added to solid medium (final concentration $10 \mu \mathrm{g} \mathrm{ml}^{-1}$ ) to identify $\mathrm{Lac}^{+}$ colonies in $E$. coli. A more sensitive fluorogenic substrate, 4-methylumbelliferyl- $\beta$-D-galactopyranoside (MUG), was used (final concentration $10 \mu \mathrm{g} \mathrm{ml}^{-1}$ ) to detect $\beta$-galactosidase activity in $B$. subtilis. 
Table 1. Bacterial strains and plasmids

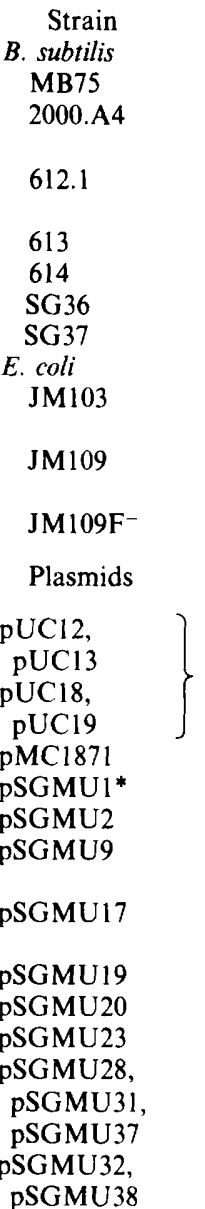

Genotype

lys-1 metC3 tal-1 spo ${ }^{+}$

hisH2 pyrDI rpoB2 tal-1 spoIIA4

hisH2 pyrD1 rpoB2 tal-l [spoIIA4] ( $\phi$ 105DS1

spoIIA $A^{+} \operatorname{spoVA^{+})}$

lys-I metC3 tal-1 spoIIAA : : lac-cat)

lys-1 metC3 tal-1 spoVAA : :lac-cat)

lys-1 metC3 tal-1 spo ${ }^{+}(\phi 105 \mathrm{~J} 19$ spoll AA : :lac-cat $)$

lys-1 metC3 tal-1 spo ${ }^{+}(\phi 105 \mathrm{~J} 20$ spoVAA : :lac-cat $)$

$\triangle\left(\right.$ lac-pro) thi-1 strA supE44 endA sbcB15 $\mathrm{F}^{\prime}$ traD36 proAB lac I $\mathrm{Z} \triangle \mathrm{M} 15$

recAl $\triangle($ lac-pro) endAI gyrA96 thi-l hsdRI7 supE44

relAl $\mathrm{F}^{\prime}$ traD36 proAB lacl' $\mathrm{Z} \triangle \mathrm{M} 1 \mathrm{~s}$

As JM109, but $\mathrm{F}^{-}$

Relevant characteristics/construction

bla lac Z', $2.7 \mathrm{kbp}$

tet lac $Z^{\prime}, 7 \cdot 3 \mathrm{kbp}$

bla cat, $4.7 \mathrm{kbp}$

bla cat, $3.7 \mathrm{kbp}$

bla cat, $4.7 \mathrm{kbp} ; 950 \mathrm{bp}$ Pvull fragment from

spoIIA/spoVA region inserted in pSGMU2

bla cat, $2.95 \mathrm{kbp} ; 224 \mathrm{bp}$ fragment from spoIIA

promoter region inserted in pSGMU2

bla cat, $4.5 \mathrm{kbp}$

bla cat, $4 \cdot 3 \mathrm{kbp}$

bla lac $Z^{+}$cat, $7 \cdot 4 \mathrm{kbp}$

bla lac $Z^{+}$cat, $7.6 \mathrm{kbp}$

bla lac $Z^{+}$cat, $7 \cdot 8 \mathrm{kbp}$

* Previously designated pSGl.
Origin

Laboratory stock

M. D. Yudkin, Oxford

Univ., UK

$\mathrm{Spo}^{+}$transductant of

2000.A4

This paper

Messing et al. (1981)

Norrander et al. (1983)

This paper

Reference

Messing (1983)

Norrander et al. (1983)

Casadaban et al. (1983)

Errington (1984)

Fort \& Errington (1985)

Fort \& Errington (1985)

P. Fort \& J. Errington (unpublished results)

This paper

Nucleotide sequencing. This was done by the chain terminator method of Sanger et al. (1977) with a kit supplied by Amersham. Buffer gradient gels and ${ }^{35}$ S-labelled nucleotides were used, as described by Biggen et al. (1983). Single-stranded phage DNA was isolated by the method of Sanger et al. (1980).

Second-strand synthesis on a single-stranded M13 template. Single-stranded phage DNA $(1 \mu \mathrm{g})$ and dideoxysequencing primer (dGTAAAACGACGGCCAGT, $0.2 \mathrm{pmol}$; Amersham) were annealed $\left(2 \mathrm{~h}, 57^{\circ} \mathrm{C}\right)$ in a $10 \mu \mathrm{l}$ reaction volume in buffer containing Tris/ $\mathrm{HCl}(10 \mathrm{mM}, \mathrm{pH} 8.0)$ and $\mathrm{MgCl}_{2}(10 \mathrm{mM})$. To the annealed template/primer mixture was added $1 \mu \mathrm{I}$ of a mixture of all four deoxynucleoside triphosphates $(0.5 \mathrm{mM}$ each) and $1 \mu \mathrm{l}$ ( 1 unit) of Klenow polymerase. After $10 \mathrm{~min}$ at $22^{\circ} \mathrm{C}$ the reaction was terminated by heating at $70^{\circ} \mathrm{C}$ for $10 \mathrm{~min}$.

Southern hybridization. Southern transfers (Southern, 1975), preparation of ${ }^{32} \mathrm{P}-$ labelled probe DNAs (Rigby et al., 1977), hybridization and autoradiography were done as described previously (Errington, 1984).

Colony hybridization. This was done essentially as described by Grunstein \& Hogness (1975). Colonies from a selective plate were picked up on $0.45 \mu \mathrm{m}$ nitrocellulose filters (Schleicher \& Schüll), then transferred for $15 \mathrm{~min}$ periods to Whatman $3 \mathrm{MM}$ filter papers soaked in the following solutions in turn: $0.5 \mathrm{M}-\mathrm{NaOH}, 1.5 \mathrm{M}-\mathrm{NaCl} ; 1.5 \mathrm{M}-$ Tris/ $\mathrm{HCl}, \mathrm{pH} 7 \cdot 5,3 \mathrm{M}-\mathrm{NaCl} ; 0.3 \mathrm{M}-\mathrm{NaCl}, 0.03 \mathrm{M}$-sodium citrate. The nitrocellulose filter was baked, hybridized to labelled probe-DNA and autoradiographed as described for Southern transfer/hybridization (Errington, 1984).

Construction of a spoIIAA : lacZ fusion. The following DNAs, predigested to completion with the enzymes shown in parentheses, were ligated in a $25 \mu \mathrm{l}$ reaction volume: $\sim 300 \mathrm{ng}$ plasmid pSGMU17 $(X b a \mathrm{I}), \sim 200 \mathrm{ng}$ plasmid pSGMU23 ( $\mathrm{Xba \textrm {I }}$ and $\mathrm{Bg} / \mathrm{II}$ ), $\sim 3 \mu \mathrm{g}$ phage $\phi 105 \mathrm{DS} \mathrm{l}\left(\mathrm{Bg} / \mathrm{II}\right.$ ). After ligation for $7 \mathrm{~h}$ at $15^{\circ} \mathrm{C}$, competent cells of strain MB75 were transformed with a $10 \mu$ sample of the ligation mixture. 
Construction of a spoVAA : : lacZ fusion. A ligation reaction similar to the one described above (total vol. $25 \mu \mathrm{l}$ ) was used, containing the following DNAs: $\sim 400 \mathrm{ng}$ plasmid pSGMU9 (EcoRI), $300 \mathrm{ng}$ plasmid pSGMU23 (SmaI and $B g l \mathrm{II}), \sim 3 \mu \mathrm{g} \phi 105 \mathrm{DS} I$ ( $B g I \mathrm{II})$. The EcoRI single-stranded ends of plasmid pSGMU9 were removed by treatment with $\mathrm{S} 1$ nuclease prior to ligation (see above). After ligation for $24 \mathrm{~h}$ at $15^{\circ} \mathrm{C}$, competent cells of strain MB75 were transformed with $10 \mu$ l ligation mixture.

\section{RESULTS AND DISCUSSION}

\section{Translational fusion plasmids}

A lac fusion cartridge incorporating a selectable chloramphenicol-resistance determinant (cat) and a series of flanking restriction endonuclease cleavage sites was constructed in a series of stages as shown in Fig. 1. The lac Z gene was obtained from plasmid pMC1871 (Casadaban et al., 1983) and the cat gene was originally from the Staphylococcus aureus plasmid pC194 (Iordanescu et al., 1978). A $1.8 \mathrm{kbp}$ fragment of DNA from plasmid pSGMU1 (Errington, 1984) that contains the cat gene was sub-cloned to a location between the BamHI and Sall sites of plasmid pUC12 (Messing, 1983) in E. coli. (In these and subsequent manipulations that required the identification of chloramphenicol resistant clones, transformants were first selected for ampicillin-resistance, encoded by the pUC portion of the plasmid, and then replica-plated to identify chloramphenicol-resistant clones. Direct selection for chloramphenicol resistance was difficult because of the relatively low-level of expression of the cat gene in E. coli.) The resultant plasmid, pSGMU19, was digested with BamHI, treated with Klenow polymerase to render the ends blunt and then digested with SalI. The $1.8 \mathrm{kbp}$ fragment containing the cat gene was isolated and cloned into plasmid pUC12 between its unique NarI (also repaired with Klenow polymerase) and Sall sites; these manipulations yielded plasmid pSGMU20. Plasmid pSGMU20 differs from $\mathrm{pUC1} 2$ in that the region of the $l a c Z^{\prime}$ gene downstream from the SalI site in the polylinker region is removed and replaced by the $1.8 \mathrm{kbp}$ DNA fragment containing the cat gene. The lac $Z^{\prime}$ gene is a segment of DNA encoding only the amino-terminal region of $\beta$ galactosidase. In a suitable host, such as strain JM103, the product of the lac $Z^{\prime}$ gene restores, by intracistronic complementation, activity to the otherwise inactive product of the lacZ $\triangle M 15$ allele. The removal of the downstream part of the $l a c Z^{\prime}$ gene was necessary to prevent it from being duplicated when the remainder of the full-length $l a c Z$ gene was subsequently introduced into the plasmid. The DNA segment encoding the cat gene in pSGMU20 is flanked by BamHI sites, one in the remaining part of the polylinker region and one reconstituted by blunt-end ligation of the repaired BamHI and NarI ends.

The $3.0 \mathrm{kbp}$ Bam HI fragment of plasmid pMC1871 contains a lacZ gene devoid only of the region encoding the amino-terminal part of the $\beta$-galactosidase protein. After treatment with S1nuclease to remove the $B a m H I$ cohesive ends, this fragment was cloned by blunt-end ligation into the unique SalI site of plasmid pSGMU20, which had been repaired by Klenow

Fig. 1. Construction of plasmid pSGMU23 and its derivatives pSGMU31 and pSGMU37 that all contained lac-cat translational fusion cartridges. Plasmids are drawn approximately to scale, with regions encoding chloramphenicol-resistance (cat), $\beta$-lactamase (bla) and $\beta$-galactosidase (lac $Z$ ) shown as boxes that indicate the direction of transcription and translation. ori indicates the approximate location of the origin of replication that enables the plasmid to replicate autonomously in $E$. coli. $Z^{\prime}$ denotes a segment of DNA encoding only the amino-terminal portion of $\beta$-galactosidase. Zig-zag lines denote break points in the coding regions of lacZ or $Z$ '. 'Polylinker' regions are shown on an expanded scale with the restriction endonucleases abbreviated as follows: B, BamHI; E, EcoRI; F, SphI; G, BgIII H, HindIII ; K, KpnI ; M, SmaI ; N, NarI ; P, PstI ; S, SalI ; T, SstI ; V, PvuII ; X, XbaI. Not all of the PvuII sites are shown. Brackets indicate that a restriction site was destroyed following blunt-end ligation. Stages involved in the construction of each plasmid are indicated by arrows and, alongside, abbreviated descriptions of the manipulations are given : limit digestions with restriction endonucleases are indicated by the name of the enzyme; 'S1 nuclease' refers to the removal of single-stranded ends from digested DNA fragments with this enzyme; 'Klenow' denotes that $3^{\prime}$-recessed cohesive ends were filled in using the Klenow fragment of DNA polymerase $I$; $\mathrm{Ap}^{\mathrm{R}}$ and $\mathrm{Cm}^{\mathrm{R}}$ stand for resistances to ampicillin and chloramphenicol, respectively. In general, the enzymic reactions were done in the order shown, and each enzyme was inactivated before proceeding to the next stage. A full account of the plasmid constructions is given in Results and Discussion. 


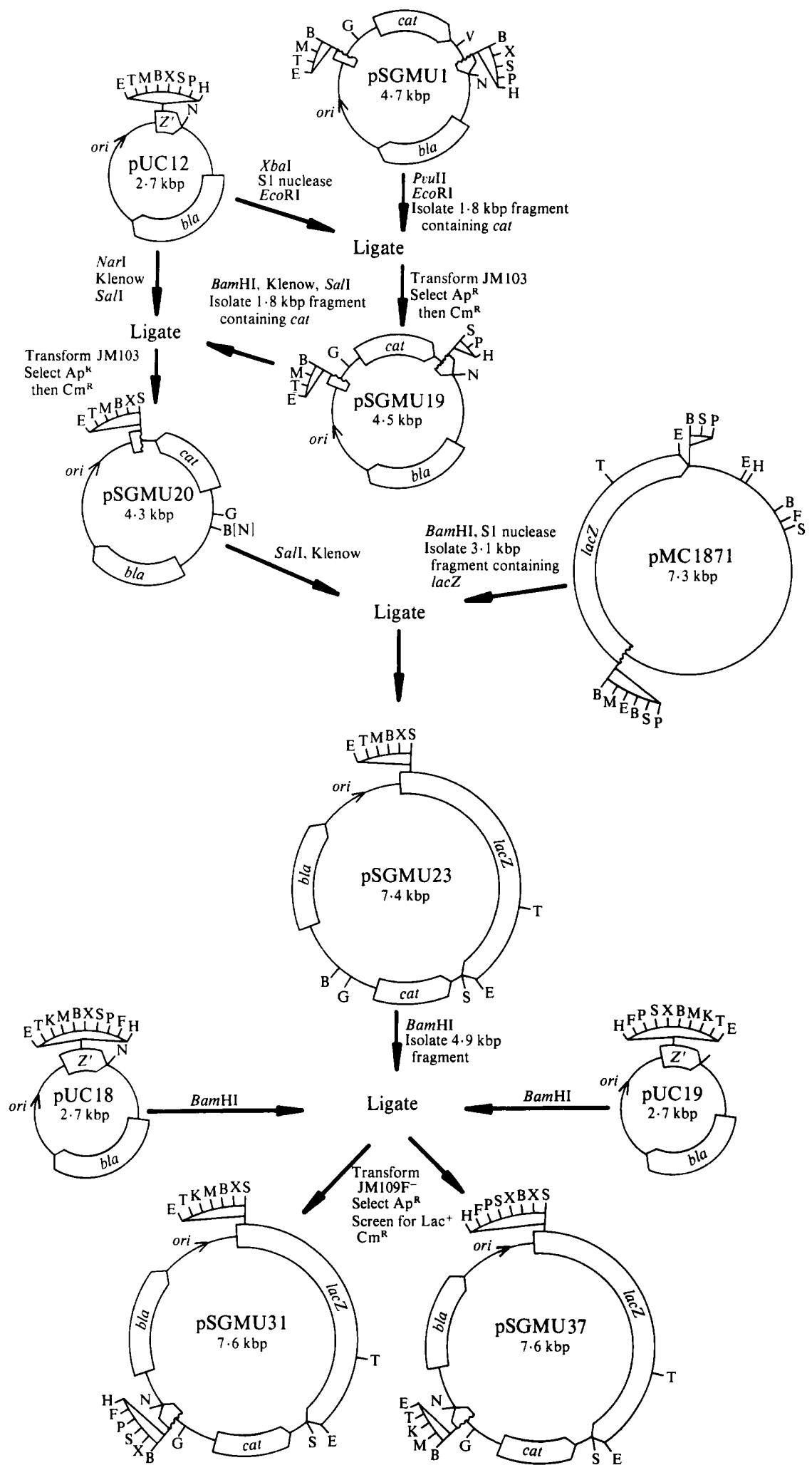


polymerase. This method of insertion was designed to give an in-frame fusion of the fragment encoding the $l a c Z$ gene to its natural promoter and translation initiation signals in the pUC. derived sequences of plasmid pSGMU20, without introducing any further BamHI sites. Ampicillin-resistant transformants were selected in strain $\mathrm{JM}_{109 \mathrm{~F}^{-}}$, from which the lac $\mathrm{Z}$ gene is completely deleted, and a $\mathrm{Lac}^{+}$colony was isolated. The resultant plasmid, pSGMU23, was shown to have the expected constitution (see Fig. 1) by restriction endonuclease analysis (data not shown). The plasmid contains a $4.8 \mathrm{kbp}$ segment of DNA incorporating both the lac $Z$ cartridge from plasmid pMC1871 and the selectable cat gene from pSGMU20. This lac-cat translational fusion cartridge can be removed from plasmid pSGMU23 with BamHI, which cleaves at both ends of the insert, or with a combination of $B g I I I$, which cleaves at the $3^{\prime}$ end of the cartridge (relative to the direction of lac $Z$ translation), and any one of the several enzymes that cleave within the $5^{\prime}$ terminus of the lac $Z$ gene.

In order to increase the versatility of the system, the cartridge was removed from plasmid pSGMU23 with BamHI and sub-cloned into the unique BamHI sites of plasmids pUC18 and pUC19. Insertion of the lac-cat translational fusion cartridge from plasmid pSGMU23 in the correct orientation generated plasmids pSGMU31 and pSGMU32, respectively. These were again selected by transforming $\mathrm{JM} 109 \mathrm{~F}^{-}$to ampicillin-resistance and screening for the production of $\beta$-galactosidase. Plasmids isolated from these strains gave the correct restriction cleavage pattern.

The predicted nucleotide sequences of the polylinker regions contained within the coding region of the $l a c Z$ gene and restriction sites at the 'downstream' end of the cartridge are given for each plasmid in Table 2. Three enzymes, EcoRI, SalI and SstI, have, in addition to any polylinker sites, a further restriction site within the cartridge. Use of these enzymes would therefore reduce the efficiency with which functional fusions can be obtained.

\section{Transcriptional fusion plasmids}

The $E$. coli lac $Z$ gene does not carry suitable translation initiation signals for efficient expression in $B$. subtilis (Donnelly \& Sonenshein, 1984). However, the translational fusion plasmids described above could be adapted to form transcriptional fusion plasmids by the insertion of a fragment of DNA containing not only the RBS but also the first few codons of a suitable $B$. subtilis gene behind the polylinker region in such a way that an in-frame fusion to the lac $Z$ gene was obtained. It seemed likely that a suitable fragment for such a construction could be obtained from the well-characterized spoIIA region of $B$. subtilis (Fort \& Piggot, 1984). This expectation was confirmed when a functional translational fusion was obtained by inserting the lac-cat cartridge from plasmid pSGMU23 into spoIIA (see below). The fused gene product is presumed to be translated from the RBS of the spoHA gene encoded by the first open reading frame of the operon (ORF1) (Fort \& Piggot, 1984), and to consist of the first 23 amino acids of the spo gene product fused in frame to the lac $Z$ gene in the polylinker region (Fig. 3). A simple procedure for modifying plasmid pSGMU23 and its derivative plasmids so that they could be used for transcriptional fusions would therefore be to insert a small fragment of DNA from the spoIIA region at the unique $X b a I$ site of plasmid pSGMU23 in such a way that the same functional gene fusion was obtained. Since this $X b a I$ site is 'downstream' from the BamHI site at the $5^{\prime}$ end of the lac-cat cartridge in plasmid pSGMU23 (Fig. 1), the fragment of DNA providing $B$. subtilis translation initiation signals for the $l a c Z$ gene would be included within the fragment of DNA released by digestion with BamHI. The new lac-cat transcriptional fusion cartridge could then be moved into plasmids pUC18 and pUC19 as described above for the translational fusion cartridge.

Plasmid pSGMU17 (P. Fort \& J. Errington, unpublished results) is a derivative of plasmid pUC13 containing a fragment of $B$. subtilis chromosomal DNA that extends from a point $150 \mathrm{bp}$ upstream from the start codon of the spoIIAA gene to an $M b o$ I site $70 \mathrm{bp}$ into the coding region of the same ORF (see Fort \& Piggot, 1984). This DNA fragment contains not only the RBS and first few codons of spoIIAA, but also all of the upstream sequences required for transcription of the spoIIA operon (data not shown). However, the promoter can be at least partially removed by cleaving at an $E c o$ RI site within the $5^{\prime}$ untranslated region of the fragment (unpublished results 


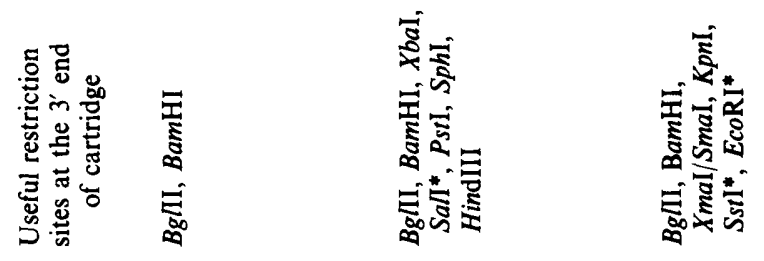

है

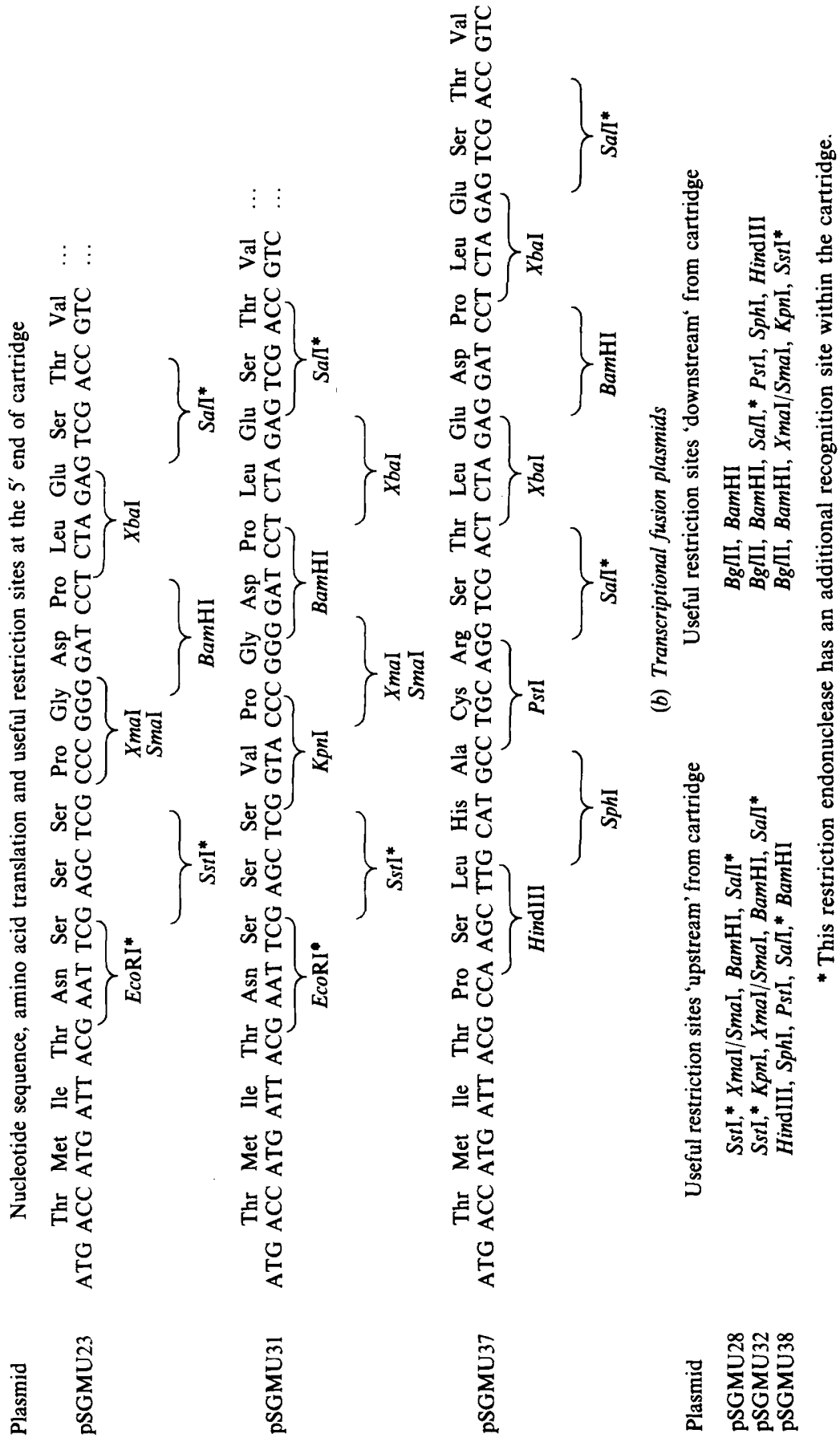




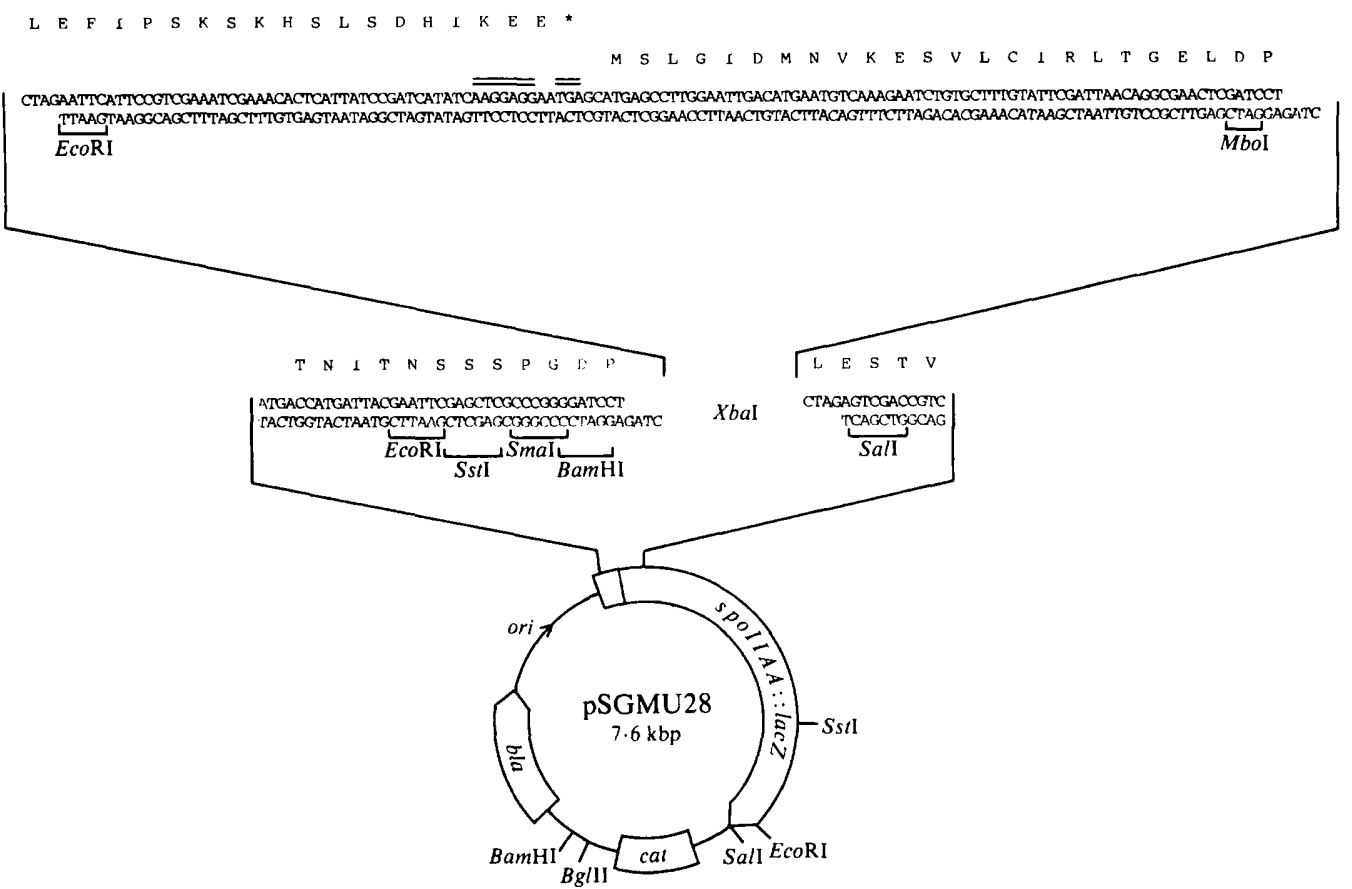

Fig. 2. Structure and construction of plasmid pSGMU28. The diagram in the lower part of the figure shows the structure of plasmid pSGMU28, containing the lac-cat transcriptional fusion cartridge (for abbreviations see Fig. 1). The nucleotide sequence of the polylinker region of this plasmid is shown above, with restriction sites and amino acid translation (standard one-letter abbreviations) indicated. The sequence is broken at an $\mathrm{XbaI}$ site into which an adapted $E c o$ RI-MboI fragment of DNA from the spoIIA region of the B. subtilis chromosome has been inserted (see text). The nucleotide sequence of this insert is shown at the top of the figure. Above the sequence, to the left, the amino acid translation is given assuming read-through from the $l a c Z$ gene. A termination codon $\left(^{*}\right)$ in this reading frame occurs within the region (overlined) that represents the ribosome binding site at the beginning of spoIIA ORF1. The reading frame chosen for the remainder of the amino acid translation is that proposed for translation of the spoIIAA gene (Fort \& Piggot, 1984) and this runs on, in-frame, into the distal portion of the $\operatorname{lac} Z$ gene to encode a fusion peptide (spoIIAA : :lacZ).

and Piggot et al., 1984). The MboI end of the fragment in plasmid pSGMU17 had been ligated to a BamHI end from the polylinker of the vector plasmid pUC13. Beyond this hybrid $B a m \mathrm{HI} / \mathrm{MboI}$ site are consecutive unique restriction sites for the enzymes $\mathrm{XbaI}$, SalI, PstI and $H$ indIII. To sub-clone the EcoRI-MboI fragment, plasmid pSGMU17 was cleaved with $E c o$ RI, treated with Klenow polymerase to fill in the single-stranded ends and then digested with PstI. The vector $\mathrm{M} 13 \mathrm{mp} 18$ was cleaved with $\mathrm{XbaI}$, treated with Klenow polymerase and digested with PstI. The target fragment was therefore cloned between the $X b a \mathrm{I}$ and PstI sites of M13mp18. The $X b a I$ site in plasmid pSGMU17 was retained in the M13mp18 derivative. At the other end of the inserted fragment, blunt-end ligation of the $X b a I$ and EcoRI ends resulted in the reconstitution of both sites (Fig. 2).

After verifying the nucleotide sequence of the insert, the insert was removed by digestion with $X b a I$, following primed second-strand synthesis on the single-stranded phage DNA template, and ligated into the unique $X b a \mathrm{I}$ site of plasmid pSGMU23. After transformation of strain $\mathrm{JM} 109 \mathrm{~F}^{-}$and selection for ampicillin-resistance, about $8 \%$ of the transformants were white on indicator plates, i.e. did not produce $\beta$-galactosidase activity. The remaining colonies were blue, and colony hybridization confirmed that approximately $5 \%$ of these contained the $X b a I$ insert. Restriction enzyme analysis of plasmid DNA from one of the colonies that showed hybridization confirmed that the construction was correct. In the new plasmid (pSGMU28), 
translation initiated at the lac $Z$ RBS would be expected to read through 19 amino acid residues to a stop codon within the RBS of spoIIA ORF1 (Fig. 2). Since the latter is translated in a different reading frame, it seems likely that the pSGMU28-encoded $\beta$-galactosidase activity is initiated, as expected, at the amino terminus of spoIIA ORF1.

The $5.2 \mathrm{kbp}$ BamHI fragment from plasmid pSGMU28 was sub-cloned into the unique BamHI sites of plasmids pUC18 and pUC19, as described above for the translational fusion cartridge. The relevant restriction sites in the lac-cat transcriptional fusion plasmids, which were designated pSGMU32 and pSGMU38 respectively, are shown in Table 2.

\section{Fusion of the lac-cat cartridge from pSGMU23 to genes in the spoIIA and spoVA operons}

The method used for insertion of the lac-cat cartridges into the $B$. subtilis chromosome depends upon the observation that a DNA fragment carrying a selectable gene, such as cat, can be rescued very efficiently onto the $B$. subtilis chromosome, during transformation of competent cells, if it is flanked by fragments of chromosomal DNA (unpublished results). This type of transformation event has been exploited previously in $B$. subtilis cloning using both phage (Kawamura et al., 1979) and plasmid (Gryczan et al., 1980) vectors.

The lac-cat cartridges in the plasmids described above can be removed using a variety of pairwise combinations of restriction endonucleases. The same enzymes (or, in some cases, a range of different enzymes) can then be used to digest cloned chromosomal DNA into fragments that can be ligated in vitro to the ends of the lac-cat cartridge. After transformation of competent cells, the flanking fragments of chromosomal DNA provide regions of homology that enable the lac-cat cartridge to be rescued on to the chromosome. By using suitable combinations of enzymes to digest the chromosomal DNA target at unique sites, the lac-cat cartridge can be inserted at a specific point. Alternatively, by using enzymes that have multiple cleavage sites, or by using sequential degradative exonucleases such as $\mathrm{Bal} 31$, or a combination of exonuclease III and nuclease S1 (Guo et al., 1983), the lac-cat cartridge can be inserted more or less at random. This procedure is therefore flexible and provides a powerful tool for investigating the control of expression of newly cloned or physically well-characterized regions. Moreover, even in the absence of an active $\beta$-galactosidase fusion product, such chromosomal insertions are highly mutagenic. By correlating the location and orientation of a series of independent chromosomal insertions (using Southern hybridization, for example) with the phenotypic consequences and the ability to express $\beta$-galactosidase, a great deal of information could be rapidly obtained on the genetic and physical organization of the cloned region.

To illustrate the use of the system described to integrate the lac-cat cartridge at a precise chromosomal location, the plasmid pSGMU23 was used to generate functional translational fusions to genes in both the spoIIA and spoVA loci. The cloning and further characterization of these loci has been described in detail elsewhere (Liu et al., 1982; Piggot et al., 1984, 1985; Savva \& Mandelstam, 1984, 1985; Fort \& Piggot, 1984; Fort \& Errington, 1985). Plasmids or phages containing suitable chromosomal DNA inserts and restriction endonuclease sites were chosen to provide fragments of homologous DNA with which to flank the lac-cat cartridge of plasmid pSGMU23. These flanking fragments enable the cartidge to be inserted by marker rescue recombination at specific sites in the $B$. subtilis chromosome, as shown in Figs 3 and 4 . In a single experiment using $1 \mu \mathrm{g}$ of ligated DNAs (see Methods), five chloramphenicol-resistant transformants of strain MB75 were obtained with the spoIIA system and 34 with the spoVA system. Individual transformants picked at random were completely stable, even when subcultured in the absence of chloramphenicol, and $\beta$-galactosidase activity was detected on nutrient agar plates containing the fluorescent indicator substrate MUG, after $24 \mathrm{~h}$ at $37^{\circ} \mathrm{C}$. The low numbers of transformants in the case of the spoIIA fusion were not surprising, considering the very small size of the 5 -flanking homologous DNA (about $200 \mathrm{bp}$ ). [The following two papers describe in detail analyses of the control of expression of both of these loci (Errington \& Mandelstam, 1986a,b).] Southern hybridization was used to verify that a single copy of the lac-cat cartridge was present in the correct chromosomal location for each strain (data not shown). 


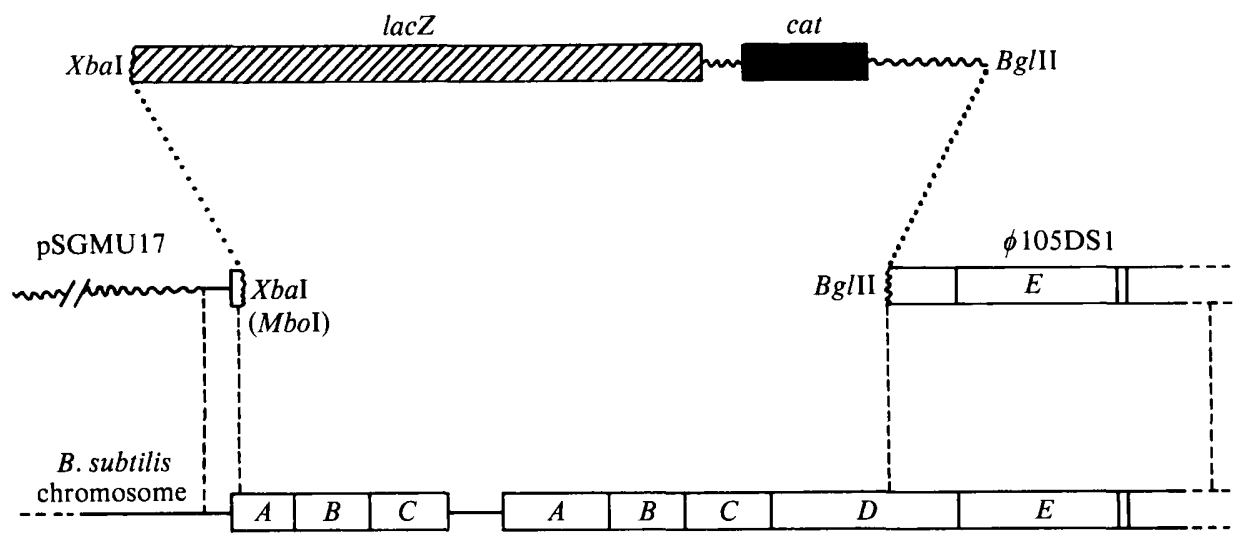

$$
\text { spoIIA operon } \overrightarrow{\text { spoVA operon }}
$$

Fig. 3. Translational fusion of the lac-cat cartridge from plasmid pSGMU23 to a gene in the spoIIA operon in $B$. subtilis. The lower part of the figure shows a physical map of the spoIIA/spoVA region of the $B$. subtilis chromosome. The spoIIA operon contains three genes (Fort \& Piggot, 1984) and the spoVA operon five genes (Fort \& Errington, 1985), as indicated by the letters in the boxes. The lac-cat cartridge was released from plasmid pSGMU23 by digestion with enzymes $X b a \mathrm{I}$ and $B g I I I$ (as shown at the top of the figure), and was ligated to DNAs containing regions homologous to the $B$. subtilis chromosome. The $X b a I$ end of the lac-cat cartridge could ligate to a segment of spoIIA DNA contained in plasmid pSGMU17 and the $B g / I$ end of the cartridge to a fragment of DNA from phage $\phi 105 \mathrm{DS} 1$. The latter fragments of DNA are shown in the middle part of the figure and are aligned over their respective regions of homology to the chromosome. Broken vertical lines indicate the limits of these regions of homology. The coding portions of the lacZ gene and the cat gene are shown as hatched boxes and solid boxes respectively. Non-coding DNA of chromosomal $(-)$ and plasmid ( $(\sim)$ origin are distinguished as shown. The end-point of the DNA insert in phage $\phi 105 \mathrm{DS} 1$ downstream from the essential part of the spoVA operon has not been determined precisely (Fort \& Errington, 1985). After ligation of the DNA molecules and transformation of strain MB75, only the arrangement shown for ligation of the participating molecules and a crossover event in both regions of homology could give rise to stable chloramphenicol-resistant colonies.

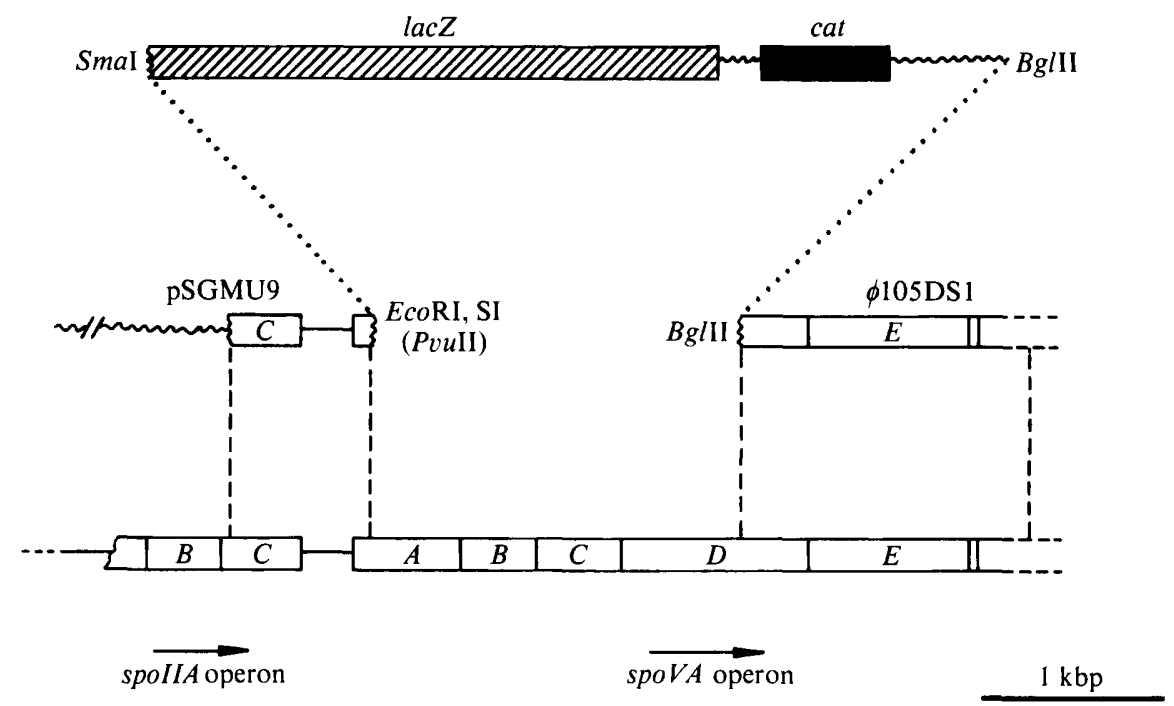

Fig. 4. Translational fusion of the lac-cat cartridge from plasmid pSGMU23 to a gene in the spoVA operon in $B$. subtilis. The arrangement of the figure is essentially similar to that in Fig. 3. Plasmid pSGMU9, containing an $0.96 \mathrm{kbp}$ PvuII fragment of DNA from the spoIIA/spoVA region (Fort \& Errington, 1985), was digested with EcoRI and then treated with S1 nuclease to obtain the correct reading frame when ligated to SmaI-digested pSGMU23. 


\section{Transfer of the spo: : lac fusions of $\phi 105 D S 1$}

Phage $\phi 105 D S 1$ (Savva \& Mandelstam, 1984) contains a $7 \mathrm{kbp}$ fragment of chromosomal DNA that complements in trans all of the known spoIIA and spoVA mutations. The ends of the chromosomal DNA fragment cloned in this phage extend beyond the junctions of chromosomal DNA and lac-cat DNA in both the spoIIA and the spoVA fusion systems. Transfer of the chromosomal lac fusions to a mobile genetic element such as phage $\phi 105$ would be useful for two main reasons. It would facilitate the more detailed characterization of the genetic elements controlling the expression of the sporulation operon. It would also enable the fusion system to be transferred conveniently, by transduction and selection for chloramphenicol resistance, into different genetic backgrounds, where, for example, the effects of different spo mutations on its expression could be evaluated [see the following papers (Errington \& Mandelstam, 1986 $a, b$; Clarke et al., 1986; Turner et al., 1986)].

The procedure for transferring the spo : : lac fusions on to the $\phi 105 D S 1$ genome was as follows. Chromosomal DNA from strains 613 (spoIIA ::lac) and 614 (spoVA::lac) was used to transform strain 612.1 , with selection for chloramphenicol resistance. The recipient strain carries the spoIIA4 mutation (mutation $4 Z$ of Ionesco \& Schaeffer, 1968), which consists of an extensive deletion involving most of both the spoIIA and spoVA operons (P. J. Piggot, personal communication), but which is phenotypically $\mathrm{Spo}^{+}$as a result of complementation by the $\phi 105 \mathrm{DS} 1$ prophage. Upon transformation, the lac-cat cartridge can be rescued (following selection for chloramphenicol resistance), by homologous recombination involving the flanking chromosomal DNA sequences, either on to the chromosome of the recipient or on to the prophage genome. In the former case the colony will remain phenotypically $\mathrm{Spo}^{+}$, since it retains intact copies of spoIIA and spoVA sequences on the prophage. However, if rescue occurs on the prophage genome, the cell becomes phenotypically $\mathrm{Spo}^{-}$, since both copies of the spo operon in the cell are disrupted. Chloramphenicol-resistant transformants were obtained at a frequency of about $10^{4}$ per $\mu \mathrm{g}$ DNA. The proportions of $\mathrm{Spo}^{-}$colonies among the transformants were $6.4 \%$ for the spoIIA : : lac fusion and $16 \%$ for the spoVA : :lac fusion. (Presumably the difference in the proportions of $\mathrm{Spo}^{+}$transformants reflects the relatively small flanking homologous DNA at the $5^{\prime}$ end of the spoIIA : :lac fusion.) Phage lysates were prepared from a single chloramphenicolresistant $\mathrm{Spo}^{-}$transformant of each type. In both cases the lysate was able to transduce sensitive cells of strain MB75 to chloramphenicol rsistance (in the presence of wild-type helper phage) and the resulting transductants, designated strains SG36 and SG37, showed appropriate control of expression of the spo: :lac fusion.

Restriction enzyme digestion of DNA from the two new phages, designated $\phi 105 \mathrm{~J} 19$ (spoIlAA : :lacZ) and $\phi 105 \mathrm{~J} 20$ (spoVAA : :lacZ), showed the expected results (Fig. 5). The largest $H$ indIII fragment $(7.0 \mathrm{kbp})$ of $\phi 105 \mathrm{DS} 1$, which contains the spoIIA/spoVA region, was increased in size by insertion of the lac-cat cartridge to approximately $8.1 \mathrm{kbp}$ in $\phi 105 \mathrm{~J} 19$ and $9.1 \mathrm{kbp}$ in $\phi 105 \mathrm{~J} 20$. After secondary digestion with $\mathrm{XbaI}$, the region of DNA upstream of the cartridge was released to give fragments of $1.2 \mathrm{kbp}$ and $2.3 \mathrm{kbp}$ respectively. (The latter fragment co-migrates with two other fragments on this gel.) These have the expected molecular masses for fragments that extend from the 'upstream' HindIII sites to the location of the spo : : lac Z fusion.

Zuber \& Losick (1983) have described the transfer of spo::lacZ fusions to specialized transducing derivatives of phage SP $\beta$ that can be used in much the same way as the $\phi 105$ derivatives described here. However, phage $\phi 105$ is much smaller $(39.2 \mathrm{~kb}$; Bugaichuk et al., $1984)$ than SP $\beta$ (118 kb; Zahler, 1982) and consequently its DNA is easier to characterize and to manipulate in vitro. Clearly the same approach could be used to transfer similar lac $Z$ fusions from chromosome to prophage for any gene cloned in $\phi 105$.

\section{Random lac Z fusions to chromosomal genes}

In principle, the plasmids described here could also be used to generate random fusions to chromosomal genes in $B$. subtilis. Plasmids such as these, which can replicate autonomously in $E$. coli but not in $B$. subtilis, can sometimes be successfuly transformed into the latter host if they carry a suitable selective marker (usually antibiotic resistance) and have a region of homology 


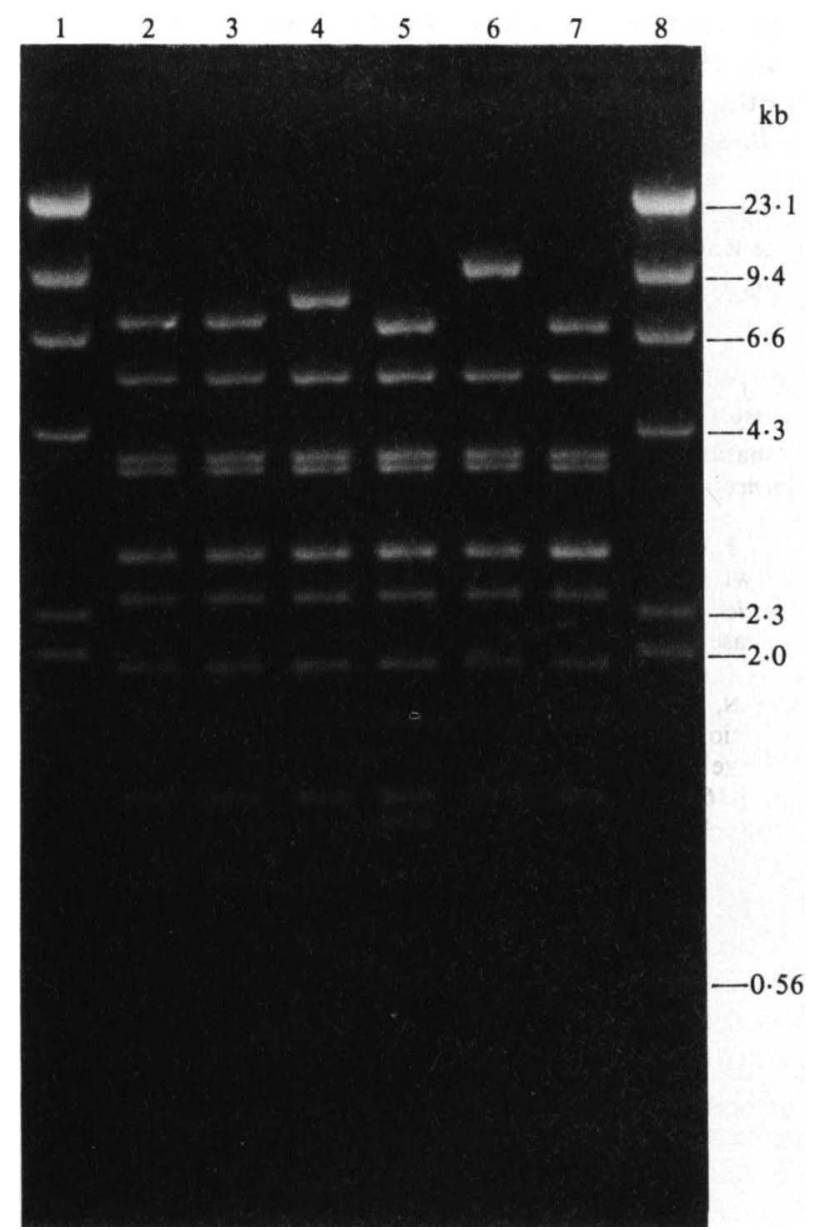

Fig. 5. Restriction enzyme analysis of bacteriophages $\phi 105 \mathrm{~J} 19$ and $\phi 105 \mathrm{~J} 20$. DNA from phages $\phi 105$ DSI (lanes 2 and 3), $\phi 105 \mathrm{~J} 19$ (lanes 4 and 5) and $\phi 105 \mathrm{~J} 20$ (lanes 6 and 7) were digested with HindIII (lanes 2, 4 and 6) or with a combination of HindIII and XbaI (lanes 3, 5 and 7). The completed digests were electrophoresed on a $0.7 \%(w / v)$ agarose gel. Lanes 1 and 8 contain molecular mass marker fragments (HindIII-digested $\lambda$ ).

with the $B$. subtilis chromosome. These transformations have been shown to occur by a single crossover event, involving the regions of homology in the plasmid and chromosome, that leads to a Campbell-like integration (Duncan et al., 1978; Haldenwang et al., 1980). Such integrational plasmids have been used for a variety of purposes; they have been used to map the chromosomal location of cloned DNAs (Haldenwang et al., 1980), to study dominance and complementation relationships (Ferrari \& Hoch, 1983), and to identify transcriptional units (Piggot et al., 1984; Fort \& Errington, 1985). Random chromosomal lac $Z$ fusions could be generated by 'shotgun' cloning $B$. subtilis chromosomal DNA fragments into any of the upstream polylinker sites of the plasmids in $E$. coli, followed by transformation of $B$. subtilis with DNA from a pool of recombinant plasmids and selection for chloramphenicol-resistance. In the transformants, the lac-cat plasmid would be integrated at sites determined by the homology between its DNA insert and the $B$. subtilis chromosome (Niaudet et al., 1982). Youngman et al. (1985) have described a system for generating essentially random chromosomal lac fusions by integration of derivatives of the transposon Tn917. A slight disadvantage with their method is the highly mutagenic nature of transposon insertions, which precludes its use for analysing the expression 
of essential genes. In contrast, the random plasmid integrations described above are often not mutagenic (Piggot et al., 1984).

In conclusion, the methods described here provide a general approach to study the regulation of gene expression in $B$. subtilis.

I thank Professor J. Mandelstam for advice and for many helpful discussions, Ms G. Roberts for excellent technical assistance, and the Royal Society for a 1983 Research Fellowship. This work was supported in part by the Science and Engineering Research Council.

\section{REFERENCES}

Biggin, M. D., Gibson, T. J. \& Hong, G. F. (1983). Buffer gradient gels and ${ }^{35} \mathrm{~S}$ label as an aid to rapid DNA sequence determination. Proceedings of the National Academy of Sciences of the United States of America 80, 3963-3965.

Brickman, E., Silhavy, T. J., Bassford, P. J., JR, Shuman, H. A. \& Beckwith, J. R. (1979). Sites within gene lac $Z$ of Escherichia coli for formation of active hybrid $\beta$-galactosidase molecules. Journal of Bacteriology 139, 13-18.

BugaichuK, U. D., Deadman, M., Errington, J. \& SAVVA, D. (1984). Restriction enzyme analysis of Bacillus subtilis bacteriophage $\phi 105$ DNA. Journal of General Microbiology 130, 2165-2167.

Casadaban, M. J., Martinez-Arias, A., Shapira, S. K. \& CHOU, J. (1983). $\beta$-Galactosidase gene fusions for analyzing gene expression in Escherichia coli and yeast. Methods in Enzymology 100, 293-308.

Clarke, S., Lopez-Diaz, I. \& Mandelstam, J. (1986). Use of lac $Z$ gene fusions to determine the dependence pattern of the sporulation gene spoIID in spo mutants of Bacillus subtilis. Journal of General Microbiology 132, 2987-2944.

Donnelly, C. E. \& Sonenshein, A. L. (1984). Promoter-probe plasmid for Bacillus subtilis. Journal of Bacteriology 157, 965-967.

Duncan, C. H., Wilson, G. A. \& Young, F. E. (1978). Mechanism of integrating foreign DNA during transformation of Bacillus subtilis. Proceedings of the National Academy of Sciences of the United States of America 75, 3664-3668.

ERRINGTON, J. (1984). Efficient Bacillus subtilis cloning system using bacteriophage vector $\phi 105 \mathrm{~J} 9$. Journal of General Microbiology 130, 2615-2628.

ERrington, J. \& Mandelstam, J. (1983). Variety of sporulation phenotypes resulting from mutations in a single regulatory locus, spoIIA, in Bacillus subtilis. Journal of General Microbiology 129, 2091-2101.

ERrington, J. \& MANDElstaM, J. (1986a). Use of a lac $Z$ gene fusion to determine the dependence pattern of sporulation operon spoIIA in spo mutants of Bacillus subtilis. Journal of General Microbiology 132, 2967-2976.

ERrington, J. \& Mandelstam, J. (1986 b). Use of a lac $Z$ gene fusion to determine the dependence pattern and the spore compartment expression of sporulation operon spoVA in spo mutants of Bacillus subtilis. Journal of General Microbiology 132, 29772985.

Ferrari, E. \& Hoch, J. A. (1983). A single copy, transducible system for complementation and dominance analyses in Bacillus subtilis. Molecular and General Genetics 189, 321-325.

FLock, J.-I. (1977). Deletion mutants of temperate
Bacillus subtilis bacteriophage $\phi 105$. Molecular and General Genetics 155, 241-247.

FORT, P. \& ERRINGTON, J. (1985). Nucleotide sequence and complementation analysis of a polycistronic sporulation operon, spoVA, in Bacillus subtilis. Journal of General Microbiology 131, 1091-1105.

FORT, P. \& Piggot, P. J. (1984). Nucleotide sequence of sporulation locus spoIIA in Bacillus subtilis. Journal of General Microbiology 130, 2147-2153.

Grunstein, M. \& Hogness, D. S. (1975). Colony hybridization: a method for the isolation of cloned DNAs that contain a specific gene. Proceedings of the National Academy of Sciences of the United States of America 72, 3961-3965.

Gryczan, T., Contente, S. \& Dubnau, D. (1980). Molecular cloning of heterologous chromosomal DNA by recombination between a plasmid vector and a homologous resident plasmid in Bacillus subtilis. Molecular and General Genetics 177, 459-467.

Guo, L.-H., YANG, R. C. A. \& WU, R. (1983). An improved strategy for rapid direct sequencing of both strands of long DNA molecules cloned in a plasmid. Nucleic Acids Research 11, 5521-5540.

Haldenwang, W. G., Banner, C. D. B., Ollington, J. F., Losick, R., Hoch, J. A., O'ConNor, M. B. \& SonENSHEIN, A. L. (1980). Mapping a cloned gene under sporulation control by insertion of a drug resistance marker into the Bacillus subtilis chromosome. Journal of Bacteriology 142, 90-98.

HiRota, Y. (1960). The effect of acridine dyes on mating type factors in Escherichia coli. Proceedings of the National Academy of Sciences of the United States of America 46, 57-64.

IONESCO, H. \& SCHAEFFER, P. (1968). Localisation chromosomique de certain mutants asporogenes de Bacillus subtilis Marburg. Annales de l'Institut Pasteur 114, 1-9.

Iordanescu, S., Surdeanu, M., Della LatTa, P. \& Novick, R. (1978). Incompatibility and molecular relationships between small staphylococcal plasmids carrying the same resistance marker. Plasmid 1, 468479.

Jenkinson, H. F. \& Mandelstam, J. (1983). Cloning of the Bacillus subtilis lys and spoIIIB genes in phage $\phi 105$. Journal of General Microbiology 129, 22292240.

Kawamura, F., Saito, H. \& IKeda, Y. (1979). A method for construction of specialized transducing phage $\rho 11$ of Bacillus subtilis. Gene 5, 87-91.

LiU, H.-M., ChaK, K. F. \& Piggot, P. J. (1982). Isolation and characterization of a recombinant plasmid carrying a functional part of the Bacillus subtilis spoIIA locus. Journal of General Microbiology 128, 2805-2812. 
Messing, J. (1983). New M13 vectors for cloning Methods in Enzymology 101, 20-78.

Messing, J., Crea, R. \& Seeburg, P. H. (1981). A system for shotgun DNA sequencing. Nucleic Acids Research 9, 309-321.

MILlER, J. (1972). Experiments in Molecular Genetics. Cold Spring Harbor, NY: Cold Spring Harbor Laboratory.

Moran, C. P., JR, Lang, N., Le Grice, S. F. J., Lee, G., Stephens, M., Sonenshein, A. L., Pero, J. \& Losick, R. (1982). Nucleotide sequences that signal the initiation of transcription and translation in Bacillus subtilis. Molecular and General Genetics 186, 339-346.

Niaudet, B., Goze, A. \& Ehrlich, S. D. (1982). Insertional mutagenesis in Bacillus subtilis: mechanism and use in gene cloning. Gene 19, 277-284.

NorRander, J., Kempe, T. \& Messing, J. (1983) Construction of improved M13 vectors using oligodeoxynucleotide-directed mutagenesis. Gene 26, 101-106.

Piggot, P. J., Curtis, C. A. M. \& Lencastre, H. DE (1984). Use of integrational plasmid vectors to demonstrate the polycistronic nature of a transcriptional unit (spoIIA) required for sporulation of Bacillus subtilis. Journal of General Microbiology 130 , 2123-2136.

Piggot, P. J., Chapman, J. W. \& Curtis, C. A. M. (1985). Analysis of the control of spo gene expression in Bacillus subtilis. In Molecular Biology of Microbial Differentiation, pp. 15-21. Edited by P. Setlow \& J. Hoch. Washington, DC: American Society for Microbiology.

Rigby, P. W. J., DieckmanN, M., Rhodes, C. \& Berg, P. (1977). Labelling deoxyribonucleic acid to high specific activity in vitro by nick translation with DNA polymerase I. Journal of Molecular Biology 113, 237-251.

Sanger, F., Nicklen, S. \& Coulson, A. R. (1977). DNA sequencing with chain-terminating inhibitors. Proceedings of the National Academy of Sciences of the United States of America 74, 5463-5467.
Sanger, F., Coulson, A. R., Barrell, B. G., Smith, A. J. H. \& ROE, B. A. (1980). Cloning in singlestranded bacteriophage as an aid to rapid DNA sequencing. Journal of Molecular Biology 143, 161 178.

SavVA, D. \& Mandelstam, J. (1984). Cloning of the Bacillus subtilis spoIIA and spoVA loci in phage $\phi 105 \mathrm{DI}$ : 1t. Journal of General Microbiology 130, 2137-2145.

SaVVA, D. \& Mandelstam, J. (1985). Use of cloned spoIIA and spoVA probes to study synthesis of mRNA in wild-type and asporogenous mutants of Bacillus subtilis. In Molecular Biology of Microbial Differentiation, pp. 55-59. Edited by P. Setlow \& J. Hoch. Washington, DC: American Society for Microbiology.

Southern, E. M. (1975). Detection of specific sequences among DNA fragments separated by gel electrophoresis. Journal of Molecular Biology 98, 503-517.

Stephens, M. A., Lang, N., Sandman, K. \& Losick, R. (1984). A promoter whose utilization is temporally regulated during sporulation in Bacillus subtilis. Journal of Molecular Biology 176, 333-348.

Turner, S. M., ERrington, J. \& Mandelstam, J. (1986). Use of a lac $Z$ gene fusion to determine the dependence pattern of sporulation operon spoIIIC in spo mutants of Bacillus subtilis: a branched pathway of expression of sporulation operons. Journal of General Microbiology 132, 2995-3003.

Youngman, P., Zuber, P., Perkins, J. B., Sandman, K., IGo, M. \& Losick, R. (1985). New ways to study developmental genes in spore-forming bacteria. Science 228, 285-291.

ZAHLER, S. A. (1982). Specialized transduction in Bacillus subtilis. In The Molecular Biology of the Bacilli, vol. 1, 269-305. Edited by D. A. Dubnau. New York \& London: Academic Press.

ZUBER, P. \& LOSICK, R. (1983). Use of a lacZ fusion to study the role of $s p o 0$ genes of Bacillus subtilis in developmental regulation. Cell 35, 275-283. 